\title{
FOREIGN LANGUAGE ACQUISITION OF SOUVENIR SELLER IN
} BAWOMATALUO VILLAGE

\author{
Saniago Dakhi \\ Nur Intan Zagoto \\ STKIP Nias Selatan \\ saniagonias@gmail.com
}

\begin{abstract}
This research is addresses language functional and lexical acquisition domains of souvenir seller in Bawomataluo village, South Nias, North Sumatera. The reasons of lexical items acquired by souvenir seller is regarded as the function of language acquisition. On the contrary, form and process of lexical items acquired are totally viewed as language lexical domains. To obtain the whole accurate data of these research problems interview and observation were conducted. The research finding indicates four specified language lexical acquisition reasons: internal motivation, external motivation, access to native speaker and experience. In addition, eight English part of speech are acquired.It is discovered that lexical items acquired are dominated by noun. Verb and adjective posites at the next level of the amount of lexicals acquired. Adverb, conjunction, pronoun are less acquired. Interjection is more easily acquired by souvenir sellers. The processes involved to acquire the lexical consist of social, memory, compensation, and affective process. Finally, the research finding is thoroughly expected to be language teacher's consideration in employing material selection and determining natural, contextual and situational language teaching model. Language leaners are highly advised to recall the language competence theoretically mastered in naturall setting in attempt to obtain practical competence.
\end{abstract}

Keywords: foreign language acquisition, souvenir seller

\begin{abstract}
Abstrak
Artikel ini berfokus pada deskripsi domain fungsional dan leksikal pemerolehan bahasa penjual sovenir di desa Bawomataluo, Nias Selatan, Sumatera Utara. Alasan pemerolehan leksikal bahasa Inggris merupakan fungsi pemerolehan bagi partisipan. Sedangkan, bentuk dan proses pemerolehanya dipandang sebagai domain leksikal bahasa. Untuk memperoleh data penelitian ini, dua jenis instrumen yang telah digunakan, yakni wawancara dan observasi. Hasil penelitian ini menunjukan empat alasan atau fungsi pemerolehan leksikal bahasa:motivasi internal,motivasi eksternal, akses terhadap penutur pertama bahasa Inggris dan pengalaman. Ada delapan jenis leksikal Bahasa Inggris yang diperoleh. Kelas kata nomina lebih dominan dikuasai, dan selanjuntnya diikuti oleh kelas kata verba dan adjektiva. Kelas kata keterangan, konjungsi, kata ganti merupakan kata yang kurang dikuasai. Kata interjeksi paling mudah dikuasai oleh penjual sovenir. Ada empat proses pemerolehanya: sosial, pengahafalan, kompensasi, dan afektif. Pada akhirnya, temuan penelitian secara menyeluruh diharapkan menjadi pertimbangan guru bahasa dalam memilih bahan ajar dan menentukan model pengajaran bahasa yang alami, kontekstual, dan situasional. Pembelajar bahasa sangat disarankan untuk mengingat kompetensi bahasa secara teoritis dan menguasai latar alami dalam upaya untuk mendapatkan kompetensi praktis.
\end{abstract}

Kata Kunci: foreign language acquisition, souvenir seller

\section{INTRODUCTION}

Language is the main vehicle of communication by which thought, idea, feeling are produced and recieved. Everybody is inseparable from the interaction with the others. The interaction highly contents of activities or processes of expressing ideas, thought, feeling, or giving information, where is commonly mentioned as communication. The 
processes of communication are embodied through language. Therefore, language is regarded as the main vehicle, since it functions to drive one's thought to the others in interaction and communication.

\section{Language is not biologically} inherited but it is mastered through some efforts. It is proved from the processes an infant does to acquire the first language. An infant is not able to communicate at once he was born. The mother tongue is gradually mastered through four stages: pre -speech, babbling stage, one word (holophratic) stage, and combining word stage. These stages gradually occur around 1,5 years old to 7 years of age. In the first stage, the infant starts to put attention to speech, intonation, and rythm of speech heard from the adults. An infant, in the second stage, starts to produce the sounds which may not be used in the given language but are found in the other language. One word stage occurrs when an infant is able to uttter the usually heard sounds. This stage continues in combining words stage where an infant utters two or more words. These proceses refer to the efforts in acquiring the language.

Psycholingistics study explains that human has the capacity to acquire and use language. This capacity is a key aspect that distinguishes humans from other beings. Although it is difficult to pin down what aspects of language are uniquely human, there are a few design features that can be found in all known forms of human language. The attempts involved in mastering the language are divided into two types, namely language acquisition and language learning. Language acquisition is the process to acquire the language naturally. Language acquisition takes place in a certain family, which is generally realized between a child and the adults in his/her surrounding through an intensive interaction. This process is closely related to the first language acquisition. Language learning is the process to master a language in formal setting. Formal settings are viewed as situation where students are learning or teachers are teaching the language in the class. This term is identically matched to the efforts in learning the second language or foreign language. It is because his/her first language is the mother tongue acquired, thus other language will be regarded as second or third language (foreign language).

The experts of language acquisition have proposed the theoritical approaches related to the first language acquisition such as cognitive theory, imitation and positive environment, and innate of certain linguistic features. Cognitive theory views the first stage of a child in acquiring language is to be aware of a concept, such as relative size, and only afterward they acquire the words and patterns to convey that concepts. It means that the ability to acquire the language is determined by cognition aspect. Imitation and 
reinforcement, behaviorist's pespective, views that infant learns by imitating and repeating what they heard from the adult. This theory shows the relationship between the stimuli and responses continuum. All the words heard by infant are regarded as the stimuli which are imitated by the infant. The action to imitate the utterances heard indicate the responses. Reinforcement, then, is given if the infant is able to produce the sounds correctly. So, it influences the infant to acquire the word and to store it in his/her memory. In the other hand, stimuli and respones are determining factors in acquiring the language. However, this theory is slowly attacked because human is capable of producing words besides what he has heard. The innate theory views differently from the behaviorist's and cognitivist's. Children are born with innate capacity of learning human language. Children discover the grammar of their language based on their own inborn grammar. In this theory, it is known a device that enables human to acquire all human languagesLanguage Acquisition Device (LAD). Chomsky $(1965 ; 1980)$ in Ellis (1985: 14) describes LAD contains a knowledge of linguistic universal these are innate and provide the child with a starting point for acquiring the grammar of the language he or he is exposed to. Chomsky believes that natural languages are governed by highly abstract and complex rules that are not immediately evident in actual utterances.
Therefore, the child must possess a set of innate principles which guide language processing.

From the approaches stated above, LAD is treated as an influential factor that supports human to acquire the languages. It is not only operated in the first language acquisition process, but also in learnig second or third language. The frequency of stimuli is inadequate for successful acquisition or learning without having LAD that activates the human's brain to proces the language.

Second language is not intended to contrast with foreign language. Winters and Johnson (199 said, "The basis for this distinction is the geographical context in which the language is spoken: an English as a Second Language (ESL) situation is one where English is widely used in commerce, administration, and education. It is a Foreign Language (FL) in a country where English plays no such role". In addition, some people learn foreign language as their second language, prominently a country who does not have their own national language like Philipine. Other veenacular may also be regarded as second language when the learner learns it after the the mother tongue acquired. For example, Nias people learn Batak language. However, in this research, the researcher emphasizes the position of English as foreign language. It is because the subjects of this research have their own vernacular- Li Niha- and national language 
- Indonesian.

$$
\text { Wibisono (1990 :67) says, }
$$

"Penguasaan bahasa kedua di lingkungan bahasa pertama biasanya diperoleh melalui pembelajaran, sedangkan penguasaan bahasa kedua di lingkungan bahasa kedua bisa diperoleh melalui pembelajaran maupun pemerolehan". It means that second language, in the first language setting, is usualy mastered through learning process, whereas second language, in second language setting, is mastered both by learning and acquisition process. It is concluded that foreign language is only acquired by learning formally and it should be mediated by an interlanguage that is national language. Finally, this articleintends to investigate the lexical acquisition reason and form as well as process how it is acquired by souvenir seller in Bawomataluo village, South Nias, Noth Sumatera.

\section{CONCEPTS AND THEORETICAL}

\section{FRAMEWORK}

\section{CONCEPTS}

\section{Concepts of Language Acquisition}

Language acquisition is the process by which human acquire to perceive, to produce, and to use words in understanding and communicating. Language acquisition is dealt with the process going in the infant's brain in acquiring his/her mother tongue. It is included in a process because a language is not acquired in relatively short time, but gradually learnt. Furthermore, language acquisition is the process by which humans acquire the capacity to perceive and comprehend language as well as to produce and use words and sentences to communicate. Language acquisition usually refers to first language acquisition, which studies infants' acquisition of their native language. This is distinguished from second language acquisition, which deals with the acquisition (in both children and adults) of additional languages.

\section{THEORETICAL FRAMEWORK}

Language acquisition is the process by which human acquire to perceive, to produce, and to use words in understanding and communicating. Human being is capable to acquire more than one languages: first language or native language, second language, third language, and so forth.First language acquisition is the language acquired by infants as their mother tough or native language. which studies infants' acquisition of their native language. This is distinguished from second language acquisition, which deals with the acquisition (in both children and adults) of additional languages.

A major question in understanding language acquisition is how these capacities are picked up by infants from the linguistic input. Input in the linguistic context is defined as "All words, contexts, and other forms of language to which a learner is exposed, relative to acquired proficiency in first or second languages". Nativists find 
it difficult to believe, considering the hugely complex nature of human languages, and the relatively limited cognitive abilities of an infant, that infants are able to acquire most aspects of language without being explicitly taught. Children, within a few years of birth, understand the grammatical rules of their native language without being explicitly taught, as one learns grammar in school. A range of theories of language acquisition have been proposed in order to explain this apparent problem. These theories, championed by the likes of Noam Chomsky and others, include innatism and Psychological nativism, in which a child is born prepared in some manner with these capacities, as opposed to other theories in which language is simply learned as other cognitive skills, including such mundane motor skills as learning to ride a bike. The conflict between the theories assuming humans are born with syntactic knowledge and those that claim all such knowledge is the product of learning from one's environment is often referred to as the "Nature vs. Nurture" debate. Some think that there are some qualities of language acquisition that the human brain is automatically wired for (a "nature" component) and some that are shaped by the particular language environment in which a person is raised (a "nurture" component). Others, especially evolutionary biologists, strongly object to assuming syntactic knowledge is genetically encoded and provided by automatic wiring of the brain.

There are three views on input in language acquisition proposed by behaviorist, nativist, and interactionist. The behaviorist view emphasizes the importance of the linguistic environment, which is treated in terms of stimuli and feedback. The nativist view minimizes the role of input and explains language development primarily in terms of the learners' internal processing mechanisms. The interactionist view sees language development as the result both of input factors and of innate of the learner and his interlocutors and involves a dynamic interplay between external and internal factors.

Behaviorist accounts of Second Language Acquisition (SLA) view the learner as 'a language-producing machine'. The linguistic environment is seen as the crucial determining factor. In this model of learning, input comprises the language made available to the learner in the form of stimuli and also that which occurs as feedback. In the case of the former, the learner interlocutor model specific forms and patterns which are internalized by the learner imitating them. Thus the availability of suitable stimuli is an important determining factor in SLA. Behaviorist theories emphasize the need to regulate the stimuli by grading the input into series of steps, so that each step constitutes the right level of difficulty for 
the level that the learner has reached. Feedback serves two proposes. It indicates when the second language (L2) utterances produced by the learner are correct and so reinforces them, and it indicates when the utterances are ill formed by correcting them. The regulation of stimuli and the provision of feedback shape the learning that takes place and lead to the formation of habits.

Nativist accounts of SLA view the learner as 'a grand initiator'. They maintain that exposure to language cannot account satisfactory for acquisition. Input is seen merely as a trigger which activates the internal mechanism. Chomsky (1965) in Ellis (1985: 128) argued that the imperfect nature of the mother's speech input in first language acquisition made it unlikely that any child successfully internalized the rule system of a language if he worked on this alone. 'Degenerate' input was inadequate for acquisition.

The third view is proposed by the interactionist. This treats the acquisition of language as the result of interaction between the learner's mental abilities and the linguistic environment. The learner's processing mechanism both determine and are determined by the nature of the input. The interaction between the external and internal factors is manifest in the actual verbal interactions in which the learner and his interlocutor participate. It follows from this interactionist view of language acquisition that the important data are not just the utterances produced by the learner, but the discourse that learner and caretaker jointly construct.

The language acquisition theorists have proposed the theoritical approaches to the first language acquisition, such as cognitive theory, imitation and positive environment, and innate of certain linguistic features. Cognitive theory views the first stage of a child in acquiring language is to be aware of a concept, such as relative size, and only afterward they acquire the words and patterns to convey that concepts. It means that the ability to acquire the language is determined by cognition aspect. Imitation and reinforcement, behaviorist's pespective, views that infant learns by imitating and repeating what they heard from the adult. This theory shows the relationship between the stimuli and responses continuum. All the words heard by infant are regarded as the stimuli which are imitated by the infant. The action to imitate the utterances heard indicate the responses. Reinforcement, then, is given if the infant is able to produce the sounds correctly. So, it influences the infant to acquire the word and to store it in his/her memory. In the other words, stimuli and responses are determining factors in acquiring the language. However, this theory is slowly attacked because human is capable of producing words besides what he has heard. The innate theory views differently from the behaviorist and cognitivist's. 
Children are born with innate capacity of learning human language. Children discover the grammar of their language based on their own inborn grammar. In this theory, it is known a device that enables human to acquire all human languagesLanguage Acquisition Device (LAD). Chomsky $(1965 ; 1980)$ in Ellis $(1985: 14)$ describes LAD contains a knowledge of linguistic universal. It is innate and provides the child with a starting point for acquiring the grammar of the language he or he is exposed to. Chomsky believes that natural languages are governed by highly abstract and complex rules that are not immediately evident in actual utterances. Therefore, the child must possess a set of innate principles which guide language processing.

The Englih grammariams classifies the words in eight parts, which is mentioned as The English Part of Speech. Thise eight parts of speech, explained in Kusnadi's book (2011: 11-132), are noun, pronoun, adjective, verb, adverb, preposition, conjunction and interjection. This part of speech is acquired by any language leaner.

Two factors of why people acquire language: internal and external factor. Internal factors are those that individual language learner brings with him or her to particular learning situation. There are six internal factors that influence the acquisition of foreign language proposed by Ellis (1985: 104-121). a) Age: second or third language acquisition is influenced by the age of the learner. Children, who already have solid literacy skills in their own language, seem to be in the best position to acquire a new language efficiently. Motivated older learner can be very successful too, but usually struggle to achieve native-speakerequivalent pronunciation and intonation.

b) Personality: introverted or anxious learners usually make slower progress, particularly in the development of oral skills. They are less likely to take advantage of opportunities to speak, or to seek out such opportunities. More outgoing students will not worry about the inevitability of making mistakes. They will take risks, and thus will give themselves much more practice.

c) Motivation: an emotional process that determine the success or failure of learner. There are two kinds of motivation: intrinsic motivation or internal motivation emerges from inside that greatly supports the success of learning for it is pushed by the interest to learn the language. Clearly, students who enjoy language learning and take pride in their progress will do better than those who do not. Extrinsic motivation or external motivation is also a significant factor. Such motivation gives low result since the base reason is not definite by his 
interest but the need of prestige.

d) Experience: learners who have acquired general knowledge and experience are in a stronger position to develop a new language than those who have not. The student, for example, who has already lived in three different countries and been exposed to various languages and cultures has a stronger base for learning a further language than the student who has not had such experiences. In the other hand, the more experiences learner has the easier the learner acquire other languages.

e) Cognition: in general, it seems that students with greater cognitive abilities will make the faster progress. Some linguists believe that there is a specific innate language learning ability that is stronger in some students' that in others.

f) Native language: who are learning a second language which is from the same language family as their first languages have, in general, a much easier task than those who are not. So, for example, a Dutch child will learn English more quickly than a Japanese child.

On the contrary, external factor includes:

a) Curriculum: for English as a second language student in particular, it is important that the totality of their educational experience is appropriate for their needs. Language learning is less likely to place if students are fully submersed into the mainstream program without any extra assistance or, conversely, not allowed to be part of the mainstream until they have reached a certain level of language proficiency.

b) Instruction: clearly, some language teachers are better than others at providing appropriate and effective learning experiences for the students in their classrooms. These students will make faster progress. The same applies to mainstream teachers in second language situations. The science teacher, for example, who is aware that she is too responsible for the students' English language development, and makes certain accommodations, will contribute to their linguistic development.

c) Culture and status: there is some evidence that students in situations where their own culture has a lower status than that of the culture in which they are learning the language make slower progress. It is expected to understand the culture of native speaker besides learning the language of native speaker. It emphasizes to avoid some problem probably emerge between the native speaker and foreigner during the conversation or discourse. In SLA, Brown (1980a: 129) in Ellis defines the acculturation model as the process of becoming adapted to a new culture. $\mathrm{He}$ explains that it is an important aspect of 
SLA, because language is one of the most observable expressions of culture and because in second (as opposed to foreign) language setting the acquisition of a new language is seen as tied to the way in which the learner's community and the target language community view each other. In addition, Schuman (1978c: 34) in Ellis (1985: 251) says, "Second language acquisition is just one aspect of acculturation and the degree to which a learner acculturates to the target language group will control the degree to which he acquires the second language".

d) Motivation: students who are given continuing, appropriate encouragement to learn by their teachers and parents will generally fare better that those who are not. For example, students from family that place little importance on language learning are likely to progress less quickly. Reinforcement is definitely smoothen the language acquisition process whether first language acquisition or second and third language acquisition.

e) Access to native speakers: the opportunity to interact with native speakers both within and outside of the classroom is a significant advantage. Native speaker are linguistic models and can provide appropriate feedback. Clearly, second language learners who have no extensive access to native speakers are likely to make slower progress, particularly in the oral/aural aspects of language acquisition.

A range competence of language used by language learner, whether as a first, second, third language, etc. is exactly different (Schembri and Orfanidou,2012). There is also tendency that third language learner is recquired to master his or her second and first language. Therefore, this study was designed to investigate the lexical items of Engish related to souvenir selling activity and the process of English is acquired. The research was carried based on the theoris of Ellis (1985: 251), Oxford (1990: 8), and Krashen (1981a; 1982) in Ellis (1985: 261-264). Ellis (1985: 248) explores the seven theories of second language acquisition process. Oxford (1990: 8) explains the second language lexical acquisition strategies. In addition, the clasification of English eight parts of speech (Kusnadi, 2011: 11-132) was also applied to categorize the lexical items in acquiring each part of speech (word class).

\section{RESEARCH FINDING AND}

\section{DISCUSSION}

\section{Kinds of Lexical Items}

Verb

There were three forms of verb found in this research, namely infinitive, present particple and past participle form. The invinitive form was divided in two forms: irregular verb and regular verb. 
Regular verb consisted of talk, help, walk, look, stay, want, etcetra, and regular verb consisted of come, have, pay, buy, meet, make, bring, etcetra. Other verbs were categorized in present participle/verb-ing form, such as walking, jumping, cooking, carving, going, making, etcetra. One verb included in past tense like married in sentence "This queen already married".

Kusnadi, in his book, explains the eight English parts of speech as it underlied the analysis of this research in terms of the kinds of lexical acquired by the subjects of this research. The analysis was started in the kinds of verb acquired. The research findings showed that there were many verbs acquired which were categorized in three forms of verb, were infinitive, present participle, and past tense. Meanwhile, Kusnadi (2011: 78-88) explaines four kinds of verb forms in English. It means that one kind of verb form was not encountered in this research, namely past participle. Based on the analysis, it was because the verbs in past participle level are most difficult to learn (Ellis, 1995). If is more efficient to learn through formal learning since it touches the study of grammar. Moreover, the native speaker tends to utilize simpler words or sentences inconversing with nonnative speakers to avoid the difficulty of meaning comprehension. The communication purpose is more emphasized in meaning rather than structure.

\section{Adjective}

The adjective form acquired was divided in three kinds, namely descriptive adjective (qualitative adjective), quantitative adjective, and numeral adjective. Decriptive adjective, such as good, big, small, were used to describe the quality of souvenirs, the condition or the situation of a place. Quantitave adjective was used to identify the quantity of uncountable noun, such as much in asking the price, for instance "How much you like?" or in claiming the high price, for example "too much" and little in sentence "little money". Another kind of speech part that firstly acquired is numeral adjectives since it closely influence the selling activities in terms of identifying the price, the number of souvenir, and telling time. From the data obtained, it was explained that one type of numeral adjective which was frequently used was cardinal number. It was started from number 'one'. Other sorts of number, such as ordinal, fraction, decimal, percentage, and arithmetic were not found in this research.

There were three types of adjectives encountered in this research; qualitative (descriptive), quantitative adjective, and numereal adjective. These findings were found in English adjectives (Kusnadi,2011: 64-69). However, two more types of adjectives were not found in this research; proper and demonstrative adjective. These encountered adjectives were the adjectives 
related to selling activities. Qualitative adjectives were used to describe the souvenir, place, or situation. Numeral adjectives were used to count the number of souvenir, or currency. Quantitave adjectives were used to identify the number of souvenir, price, and time. Therefore, it was concluded that the research finding is in line with theory

\section{Noun}

The noun found from the pariticipants' explanation were classified in five kinds, namely common noun, compound noun, abstract noun, verbal noun, and proper noun. Common noun included personals such as: king, queen, father, farmer,boy, girl; animals, such as pig, chicken, fish; places for example house, room, beach, lake, shop; nature like stone; vehicles, for instance car, motorbike; tools, for example knife, spear, and stick; plants for example tree, banana, rice, and potato; and cloths, such as $t$-shirt, hat, and shoes. Compound noun was few acquired by participants, for example meeting house, office government, souvenir shop, and stone jumping. Abstract noun consisted of some example were story, generation, memory, story, symbol, religion, problem, time, power, and price. It was found some verbal nouns, such as figthing, meeting, carving, walking, jumping, and cooking. Other forms of noun found was proper noun, for example Sunday, Monday, America, Lagundri, etcetra.

The kinds of noun explained in Kusnadi's book (2011: 11- 18) were all encountered in the research. The research finding was decided in line with the theory that nouns are conidered the easiest to learn, being more likely to evoke images and thus more meaningful, whereas verbs and adverbs are the most difficult to learn (Ellis, 1993). For these reasons, nouns whose referents were people or objects of everyday use were selected. It means that the acquisition of noun is easier since the acquirer easily perceive the name of the objects or images he/she heard from the speaker. Hence, the word class acquired was dominated by nouns.

\section{Adverb}

The adverb discovered from this research consisted of two classes, were the adverb of time and place. The data related to the class of the adverb of time were given by the nine participants (p1-p9, A.1), such as today, tomorrow, yesterday, next time, next year, next monts, three days, five days, now, one month, and one week. The data dealt with the class adverb of place were also given by the nine participants. However, it was few found the example of this class, for example here and there.

The adverb of English explained in Kusnadi's book (2011: 90-92) consists of six kinds, are adverb of time, place, number, manner, quantity, and affirming/ 
denying. Two of these were found in this research: adverb of time and place. Based on the previous research in account of lexical acquisition, it was explained that adverbs are one of the ward class that were mostly acquired (Ellis, 1995). The adverbs of manner (for example, quicklyhappily) which is morphologically marked by inflectional and derivational were not acquired. As found in previous research that confusions between forms that are clearly morphologically marked suggest that learners do not recognize these derivational suffixes as markers of word class. In other words, they are lacking syntactic morphological knowledge (Tyler \& Nagy, 1989: 649-667) that involves knowing that a particular derivational suffix marks a word for a specific lexical category. Therefore, the more difficult adverbs were not acquired.

\section{Interjection}

The interjection found and frequently used by participants were $o h, h i$, hello, yes, and okay. This sort of word class was easily acquired by participant, because their usage is more common and more often.

\section{Pronoun}

There was found two kinds of pronouns from the interview result. The first was personal pronoun which was divided in two forms, namely subject, for example $I$ (first singular person), you (second singular person), he (third singular person), they (third plural person), and we (first plural person); and object, for example me and you. The second was possessive adjective, by which consisted of three kind only, namely your, $m y$, his, and its.

Kusnadi (2011: 48-56) explains the kinds of pronoun in English. However, several kinds were not found, such as she,our, their, them, us, him, her, mine, ours,theirs, hers, his, yours. Reflexi and relative pronouns were also not acquired. It was analyzed that the omision of such pronouns was caused by the limited involvement of communication elements, or such pronouns were rarely uttered in participants' discourse.

\section{Conjunction}

The class of conjunction found in this research was coordinating. It consited of three exapmles, were and, or, and but. It was shown in some utterances of participants during conversing with foreigners.

The types of conjunctions explained in Kusnadi (2011: 121-129) consist of three, are coordinating, correlative and subordinating conjunction, but only one type of conjucntion acquired. The data showed that the native speakers more often utilize one word and short sentence. It aims at avoiding the difficulty of sellers's comprehension toward their utterance. 


\section{Preposition}

Only one type of preposition found in this research was simple preposition. This type consisted of at, for, to,up, from and $o f$.

From the data obtained, four examples of simple preposition in English were acquired by participants as it was explained previously. Whereas in Kusnadi's book (2011: 97- 101), it is explained six kinds of prepositions. The limitation of this preposition acquisition was because the native speakers tend to use comon and more easily understood words.

\section{Process of Lexical Acquition}

The second research finding concerned with the strategies of participants in acquiring the lexicals of English. Through the interview, it was found four strategies attempted by participants, namely social, memory, compensation, and affective strategy. These present findings were compared with the post research findings (theories applied in this research).

From the research data, it was dicovered four lexical acquisition strategies applied by the nine participants. The first strategy explained was social strategy. Social strategy was mostly used by the nine participants where the participants tried to cooperate with the other to help them understand what foreigners had said. Besides, asking the foreigner to repeat what they said and asking the other who have known the meaning of the lexical become a helpful way for them to perceive the unfamiliar words. In addition, there emerged empathy between the foreigner as native speakers and souvenir sellers. In the other word, the foreigners and souvenir seller tended to understand each other if it was difficult for them to understand what they meant. This finding is in line with theory of social strategy explained in chapter II. Oxford (1990: 8) explaines that social strategies are very important in learning a language because language is used in communicationand communication occurs between people. Three sets of strategies are included in this group: asking questions, cooperating with others, and empathizing with others.

The second was memory strategy. It was found from the participants' experience that the native speakers usually make use the object they meant or point out to the object they inteded, so the participants associated the words they heard with the object pointed. Repeatedly heard words, then,were memorized or stored in their memory (mental dictionary). In addition, if the participants got difficult to interpretwhat the foreigners had said, they pay attention to the foreigners'gesture. This finding was in relevence with the theory of memory strategy explore in chapter II, where Oxford (1990: 8) explaines that memory strategies are based on simple principles like laying things out in order, making association, and review- 
ing. These principles are employed when a learner faces challenge of vocabulary learning. The words and phrases can be associated with visual images that can be stored and retrieved for communication. Many learners make use of visual images, but some find it easy to connect words and phrases with sound, motion or touch.

The third was compensation strategy. Participants made use this strategy to comprehend the target language when they got difficult to perceive the native speaker utterance. Guessing the meaning was an aid for the participants to understand the targer language. In this strategy, the way to guess the meaning was based on the daily experience, especially in selling activities. Some words were particularly utilized in selling, for example the word "much, expensive, and cheap" have coherrence with the price identification, "stone, knife, spear, shield, statue, necklace" are related to carving activities, etcetra. The participants, hence, connect such words with its meaning by bringing thier own experience of selling. This finding was in reference with the theory of compensation strategy which was explained in chapter II, by which Oxford (1990: 8) declares that learners use compensation strategies for comprehension of the target language when they have insufficient knowledge of the target language. These strategies make up for the deficiency in grammar and vocabulary. When learners do not know new words and expressions, they guess the meaning. A learner brings own life experience to interpret data by guessing.

The fourth was affective strategy by which linked with the participants' attitude, emotion, and motivation. The participants explained that their progress was supported by thier own attitude. How they behaved to foreigners when they did not understand the word meaning, or how they attempt to comprehend the foreigners' utterance will cause whether slow or more progress. Having self-confidence to perform their ability, encouragement to produce the sounds of English, and behaving politely with foreigners aid them to make more progress. This finding was in line with the theory applied in this research, where Oxford (1990: 8) explains, "the affective factors like emotion, attitude, motivation, and values influence learning in an important way. Three sets of strategies are included in this group: lowering your anxiety, encouraging yourself, and taking your emotional temperature". In addition, Krashen in Ellis (1985: 263) states that affective filter controls how much input is converted into intake. It is affective because the factors which determine its strength have to do with the learner's motivation, self-confidence, or anxiety state. Learners with high motivation, selfconfidence, or low anxiety have low filters and so obtain and let in plenti of input. Learners with low motivation, little selfconfidence, or high anxiety have high filter 
and so receive little input and allow even less in.

\section{The Implication of Research Finding}

The result of this research is considered to give some accounts in teaching English as foreign language:

a) Teaching English is not totally organized in formal setting. Many students complain the learning situation that takes place in classroom. The counscious learning implicitly expects the ability in writing rather than speaking ability, the students feel presured, low motivation and low selfconfidence in using English, consequantly teaching English should be more emphasized in real practice (natural setting). It was discussed in chapter II that language development should be considered in terms of how the learner discovers the meaning potential of language by participating in communication. In accordance with the research findings, the more outgoing participants were those who frequently spoke to native speakers. Two of nine participants (p3 and p8) acquired much vocabularies, since they more often spoke to native speakers. Therefore, to improve the students' speaking ability, it is important to involve the students in practicing, both with their peers or teacher and native speakers.

b) Teaching English is highly influenced by the knowledge of categorizing each word in part of speech, since every word and sentence produced is structed from word class. It helps the students to construct good sentence both in writing and speaking. The finding of this research showed that there were some grammatical error in participants' utterances, for example, me for garden, and me carving ( 7 , A1). The pronoun ' $\boldsymbol{m} \boldsymbol{e}$ ' in two sentences should be placed as object, not subject. It is caused by the lack of knowledge in using each word functionally.

c) The English teachers' role in growing the students' motivation, attitude, and self-confidence in learning English is much expected. Many students look passive in practicing their competence. They are able to express their thoughts by using English only in written form, but are lazy to perform their ability orally. It is the influence of their affective or personality asspect toward the language they are learning. The nine participants produces some grammatical errors, both in sentence structure and pronunciation, but they can participate in communication with native speakers. It was because they showed good affective or personality (having high self-confidence, encouragement, and motivation), since the effect of affective or personality is important in learning and using the learnt other languages. 


\section{CONCLUSIONS}

To sum up, four specified language lexical acquisition reasons found out: internal motivation, external motivation, access to native speaker and experience. In addition, eight English part of speech are acquired.It is discovered that lexical items acquired are dominated by noun. Verb and adjective posites at the next level of the amount of lexicals acquired. Adverb, conjunction, pronoun are less acquired. Interjection is more easily acquired by souvenir sellers. The processes involved to acquire the lexical consist of social, memory, compensation, and affective process.

\section{ACKNOWLEDGEMENTS}

The great gratidue is addressed to Dr. Misra Umiyati who always reminds and supports the writer to publish this article on RETORIKA-Jurnal ilmu bahasa Program Studi Magister Linguistik Program Pascasarjana Universitas Warmadewa as the medium for communicating the research to other linguistic scholars. Special appreciation is for Nur Intan Zagoto as the team member of the project.

\section{REFERENCES}

Dardjowidjoyo, S. 2005. PsikolinguistikPengantar Pemahaman Bahasa Manusia. Jakarta: Unika Atma Jaya Yayasan Obor Indonesia.

Ellis, R. 1985. Understanding Second Language Acquisition. Great Britain: Oxford University Press.

Ellis, R. 1995. Modified Oral Input and the
Acquisition of Word Meanings. Applied Linguistics.Rowley, MA: Newbury House.

Gass, S. 1988. Integrating Research Areas: A Framework for Second Language Studies. Applied Linguistics. Mahwah, NJ: Erlbaum

Hunt, A and Beglar, D. 2005. A framework for developing EFL reading vocabulary. Reading in a Foreign Language, Volume 17(1), April 2005. Retrieved from http://wenku.baidu.com/ view/70c2c70c52ea551810a687da.html

Krashen, S. 2013. Second Language Acquisition: Theory, Applications, and Some Conjecturs. Cambridge: Cambridge University Press.

Kridalaksana, H. 2007. Kelas Kata dalam Bahasa Indonesia. Jakarta: Gramedia Pustaka Utama.

Kusnadi. 2011. Complete English Grammar. Jakarta: Bintang Usaha Jaya.

Laufer, B. 1998. The Development of Passive and Active Vocabulary in a Second Language: Same or Different? Applied Linguistics. Rowley, MA: Newbury House

Oxford, R. 1990. Language Learning Strategies: What Every Teacher Should Know. Boston: Heinle \& Heinle.

Schembri, A. and Orfanidou, E. 2012. First language acquisition differs from second language acquisition in prelingually deaf signers: Evidence from sensitivity to grammaticality judgement in British Sign Language. Retrieved from http:// www.ncbi.nlm.nih.gov/pmc/articles/ PMC3657148/

Segler, T.M., Pain, H., Sorace, A. 20002. Second Language Vocabulary Acquisition and Learning Strategies in ICALL Environments. Computer Assisted Language Learning.

Singleton, D. 1999. Exploring the Second Language Mental Lexicon. Cambridge: Cambridge University Press.

Tyler , A. , and Nagy , W . 1989. The Acquisition of English Derivational Morphology . Urbana: University of Illinois at Urbana-Champaign Press.

Wibisono, Y. 1990. Bahasa dan Pemerolehanya. Jakarta: Unika Atma Jaya Yayasan Obor Indonesia.

Winters, S. and Johnson, K. 1998. An exemplar -based model of silent-center syllable perception. The Sound of the Future: A Global View of Acoustics in the 21st Century, Proceedings 16th 
International Congress on Acoustics and 135th Meeting Acoustical Society of America. pp. 2021-2.

Appendix 1. The Data Reduction of The participants' Explanationof the Lexical Acquired 